Vol. 1, 2019

\title{
The role of experiences and sociability networks in the construction of narratives in enterprises
}

\author{
B.A. Rafael Baldomero López Lozano \\ National University of San Marcos, Lima, Peru \\ lopezlozanorafael@gmail.com
}

\begin{abstract}
This article seeks to know the role of experiences and networks of sociability in the nation's narratives among a group of businessmen and executives belonging to various business associations in Lima. These perceptions, representations and experiences were developed within the framework of the thesis "Analysis of the discourse on Peruvian society in the main business associations of Lima". Thus, research stems from the need to study the most privileged sectors of Peruvian society from anthropology because it helps to understand how power is exercised in Latin America.
\end{abstract}

Keywords. Sociability networks, construction of narratives, enterprises

\section{Introduction}

This article aims to know the role of experiences and networks of sociability in the narratives of the nation between businessmen and executives in Lima. This was developed as part of the thesis "Analysis of the discourse on Peruvian society in the main business associations of Lima" presented at the UNMSM in April 2019, which talks about the need to study the business sector from anthropology because it implies understanding As within Latin American societies, power is exercised. In this way, this research seeks to take a turn in anthropology by studying the most privileged sectors of a country.

The information was obtained after a series of conversations with businessmen and executives affiliated with different business associations in Lima, Peru. In them, the interviewees were asked to draw a parallel between their professional lives along with the political context they had to live and develop a narrative. Thus, it was possible to know how the leaders of the main economic unions nationwide at the beginning of this century conceive the Peruvian nation.

The objective was to know how the leaders of the main economic unions nationwide at the beginning of this century conceive the Peruvian nation. All this under the following questions: what is the sociopolitical context that originates these perceptions and representations of Peruvian business leaders at the beginning of the 21st century? What representations do these people have about Peruvian society and the actors that compose it? How do your personal experiences relate to the generation of these perceptions and representations? This allows us to understand how the vision of the country in Peruvian society has changed, from a dominant class (Cotler, 1978) to a leader in the respective field to translate a country vision, making it hegemonic. 
The document is divided into three parts. First, general information is provided, describing the methodology used and providing a historical context on entrepreneurs in Peru. Then, a bibliographic review is made of economic elites, what is being said when we refer to reflexivity, narratives and nationalisms with the purpose of providing analytical tools. And thirdly, we present what was said in the conversations about the experiences that most influenced the generation of these.

\section{Case study: the Lima business sector}

\subsection{Conversation dynamics}

For this article, we talked with various members of the Lima business sector to learn about their professional careers within the social context of the country. Some can be described as life stories and others as in-depth interviews. In that sense, we share the most general features to help the reader contextualize.

Twenty interviews were conducted with businessmen and executives. The duration of each one depended on the dynamics and some topics deepened. All respondents live in Lima, with most of the conversations in the Lima districts of San Isidro, Miraflores and Surco.

Of the 20 respondents, 6 belong to industry, 4 to commerce, 4 to mining and the rest are in fishing, agriculture and marketing. In the case of industrialists, branches such as textiles, clothing, metalworking, beverages and food were covered. Then, on the commercial side, most of the people belonging to this sector held managerial positions.

Taking as reference the property, there are two groups: those who are linked to the ownership of the companies and the managers in charge of corporate governance. The former are considered those people who make the final decisions because they or their family ultimately maintain ownership and control. Depending on the case, the control is delegated to a third party for the administration of your business, there being a very close relationship between the two.

Executives are any person professionally employed to occupy the highest positions in decision making within corporate governance. They have no ownership of it, they are hired by the owners, but they are professionally trained to administer. This is reflected in, for example, that all executives interviewed have masters and graduates in Senior Management.

Regarding their study centers, most attended private universities in Lima or a College in the United States. There is also another group that studied in public institutions such as the National Engineering University. While all are licensed, an interesting group has master's degrees, obtained both in the United States, Europe or Latin America.

And, regarding their links with the public sector, 05 of the 20 respondents held positions of trust from the governments of Alberto Fujimori (1990-2000) to Ollanta Humala (2011-2016). Also, 02 respondents are part of various law firms that collaborated with the State in modifications of laws and privatizations. Thus, a group that stands out for its experience both in the private sector and in the public sector.

\subsection{Business history in Lima: grouping into unions.}

Throughout Republican history, the interaction between businessmen and public actors has been constant and fluid (Durand, 2018). Of these, the guilds can be considered the face of a certain group vis-à-vis the rest of society. Therefore, knowing its history helps to understand which processes are the most important in the formation of a country vision.

The history of business associations regarding institutions is relatively recent: between 1884-1895. In that period, the Lima Chamber of Commerce was born as heiress of the former Colonial Consulate Court, an entity that mediated trade disputes.

During the twentieth century, the relationship between owners and public officials was close because the Lima Chamber of Commerce was the only union and functioned as a link between the political world and the business world. Afterwards, the former Agriculture and Mining Society is separated into three independent unions: the National Agrarian Society, the National Society of Industries and the National Mining Society because the state development offices needed independent associations that could be at their own pace. 
The National Society of Industries was born on June 12, 1896 because the momentum of industrial activity takes on more prominence in the economic life of the country. Then, in the sixties, he began to found other institutions with the aim of linking with society. as the SENATI institute with the purpose of training young operators. In parallel, the National Agrarian Society was born which, according to Burga and Flores (1980), advocated a classical economic liberalism together with a Catholic conservatism in politics. On the other hand, the National Mining, Petroleum and Energy Society was very close to the government during the dictatorship of Odria (1948-1956) in the elaboration of a new Mining Code with a strong liberal component.

During the military government (1968-1980), the unions begin to have greater institutionalization because the reforms implemented by the State make greater unity necessary. With the return to democracy in 1980, they can reuse the acronym of national in their official name and follow a vision of a country that privileged the economic over the political.

Then, in the second half of the century, other unions such as the National Fisheries Society (1952) were born because of the growth of the fisheries committee of the Society of Industries. This was so great that it made the formation of an independent guild necessary. Another union that emerges from the SNI is the Association of Exporters in 1973. This was born with the aim of promoting and defending foreign trade in the middle of the military government, becoming more prominent in the eighties because of the existence of a more market closed and there was greater economic protection.

The changes in the Fujimori government (1990-2000) produce even more separations because new groups viewed with suspicion the practices maintained within the more traditional associations. In that context, COMEX Peru was born with the purpose of promoting the Free Trade Agreement with the United States and the insertion of Peru in the Asia-Pacific forums.

All the unions are currently grouped within CONFIEP, except the S.N.I, ADEX and the Chamber of Commerce. This was born on November 12, 1984 with the aim of defending principles and not interests within a context of advancement of the social movements of the left. Over the years, he has been the most important interlocutor between the public and private sectors.

According to a former president of the S.N.I interviewed, the problems arise because the president began to monopolize functions, distorting union activity. It is within the retirement of industrialists, in times of President Toledo (2001-2006), where the FTA negotiations take place. Thus, within the unions there were two groups: for those who saw the FTAs as a threat and for whom it was a new business opportunity. In that last dispute, the "liberals" imposed themselves on the "mercantilists." In summary, we can appreciate that the history of business associations in Lima has not been linear, but was full of alliances, separations, hegemonies and disputes. On the other hand, we see that at each stage the economic model determined the correlation of forces. Thus, the dynamics of the unions have consisted of fostering and adapting to the different social situations, where some groups impose themselves on others.

\section{Economic elites and nation}

\subsection{Studies on entrepreneurs in Peru from the social sciences}

For this article, it is important to know other studies that worked on the relationship between businessmen and nation. In the first place, this is not new and has always been present in the Peruvian intellectual tradition. Within the social sciences, it has been recurring to think about how the most privileged sectors are.

As noted, the first serious research on entrepreneurs from the social sciences had a militant purpose. At that time the idea was to recognize the nature of the ruling class in order to delimit a revolutionary strategy (Malpica, 1964). Thus, businessmen associated with oligarchy, taking as a common denominator that this group had wealth, power and was organized into families (Cotler, 1978). Because field work was never done, prejudice was formed of an oligarchy with a dominant but not leading position (Rénique, 2008).

With the end of the military government (1980) the term oligarchy was no longer used but an economic group to study businessmen (Alcorta, 1989). This is due to the influence of the departments of economics, which sought to study the development of their wealth. This occurs within the 
framework of the introduction of neoliberal reforms in our country and the objective was to know the impact of these economic policies on Peruvian economic life (Anaya, 1990).

In the new millennium, new themes are developed, from gender to informal lobby networks (Ramos, 2014) because business groups are seen as part of the most privileged sector of society: a "high class" (Kogan, 1999). In general, the central problem addressed in the research was the impact of economic as well as political and social inequalities (Campodónico and Durand, 2018). On the other hand, there are studies prepared by the same business associations that, although they are laudatory, show a story about the role played by entrepreneurs in the construction of Peruvian nationality (Reyes, 2008).

Therefore, we observe the issue of nation indirectly in most previous research. Although their central object of study was the exercise of power, they leave some loose ideas about the vision of society of this group. This, then, has a lot to do with the representation of a political community, which is the nation.

\subsection{Reflexivity, narratives and nation in anthropology}

The importance of talking about reflexivity, narratives and nation lies in providing reference categories capable of providing conceptual support for empirical research. Thus, before talking about what was said by the interviewees, we must understand that it is certain experiences and networks of sociability that generate narratives and reflexivity in the actors.

In social groups, together with their perception and appreciation schemes, there is a struggle within the social space to impose a certain vision of the world (Boudieu, 2011). According to our subject of study, respondents generate their perceptions largely thanks to the interaction offered by the guilds as spaces of socialization and product of their own personal stories.

In that sense, we must appreciate the need for narratives since they are part of how a social group sees the world and acts on it (Jimeno, 2016). These should be studied according to the meaning of the messages that the subjects seek to transmit within the place where the speeches are enunciated, but taking into account their social origin. Therefore, narratives are a way of seeing the social reality part of the interviewees born from their own experiences and networks (García-Huidobro, 2016).

It is useful to talk about the influence of experience and social networks in the nation's narrative because it is to think about how the political community is built and the role we play in its formation. Talking about a nation helps us understand the ways of thinking about the management of society and the types of leadership that may exist, better understanding power relations.

The nation and nationalisms are an imagined community (Anderson, 1993) born in the context of the world-economy (Wallerstein, 2006) and the emergence of mass politics (Hobsbawm, 1997). This should be studied from the social reflexivity of the agents as well as in the construction of narratives within a heterogeneous time where there is a content, articulated with power relations (Chatterjee, 2002).

In Peru, according to what has been previously investigated, it is argued that the most privileged groups did not develop a political program and neither did a project that brought together other classes, worrying little about constituting an organic group of intellectuals that would help their domination (Burga y Flores, 1980). What there is, they comment, is a mythical image of Peruvian history in which the Hispanic elements were exalted in an unconscious way. At a general level, the Peruvian State based itself on the customer relations that the different oligarchic groups had established with both the subordinate population and foreign capital (Cotler, 1978).

In that way, the nation can be seen as an imagined community typical of the world economy. In parallel, mass politics generates a popular nationalism, which must be analyzed from the perspective of demos (political community) and ethnos (cultural community), the product of the agents' social reflexivity (Balibar, 2003). Therefore, in parallel to the history of nationalisms there must be a history of the history of nationalisms (Palti, 2003).

It is possible then to affirm the following. 1). people generate their perception and appreciation schemes because of their interaction in everyday social life. two). These thought schemes born of reflexivity generate different conceptions of social reality. And 3) the nation and nationalism is a specific form of representation schemes of a collective that revolve around the political community and the cultural community, crossed by power relations. 


\section{Results of the investigation}

\subsection{Most important experiences that influenced the country representations of the interviewees}

The experiences most mentioned by the interviewees have to do with their training in their early stages of socialization. They motivated their relationship with the reality of the rest of the country to acquire a certain form. We have seen that both families and educational institutions have a significant influence on the generation of their perceptions of the country.

First, the family stands as the main educational institution in terms of principles and representations. Before, they were more traditional because there was a confusion between the authority of father and man. That was seen with greater emphasis on the formation of women, particularly for those who came from religious schools. This implied that the father had a fundamental weight and many women favored machismo.

On the other hand, the trajectory of their relatives around their merits, mostly academic or their business skills, is frequently highlighted. In that sense, one must gain his place because complying with what one has would mean being mediocre and living off past achievements. The most important premise is: "children must surpass parents in terms of success." If people do not work in business, it should be in another field because the important thing is to make merits.

In relation to business, many were trained in family businesses but mentioned that there should be no privileges and should start from below. For example, despite being her father one of the founding partners, an industrialist says that she started from the bottom as a programmer and her German upbringing imparts a series of values such as honesty and hard work, there is a work ethic to honor The name of the grandparents.

Finally, a fundamental aspect is the religious formation in the school. This is because it is where good things like solidarity and other bad things like hierarchy are learned. In the case of higher education, there are two groups: those who studied in Peru and those who studied abroad where they studied in Peru was in a private university. In the case of those who studied abroad, normally the destination was the United States, they gained some independent experience but end up returning in order to support family businesses. In both cases, the built networks are important and are reinforced with the postgraduates because more capital.

\subsection{Influence of these institutions in the generation of their principles and representations}

In this part we seek to explain how experiences influenced the formation of representations. All attribute to family and school-university education. Thus, we can affirm that these institutions have a fundamental role.

The idea of respect is marked by having undergone a very traditional education. In this case, the values are incorporated through family circles. In parallel, we also appreciate the role attributed to the school lies in the predisposition to instill in students the social issue. Another institution that stands out is the university, highlighting the Catholic University and the National University of Engineering, which are remembered as places of much ideological debate. Thus, it influenced the formation of his political conceptions.

\subsection{Institutions where they entered the corporate world}

The entry into the corporate world is given through two institutions: the chosen career and the previous links. So that 10 of the 13 businessmen interviewed got involved in business seeing their parents' experience and were building experience even before entering. However, you should not start "from below" and show what is worth because you cannot manage well what is not known and deceit is also avoided.

Another important event as the first job was obtained because this allows them to have a vision of how things are and interact with different actors, protected by the group. On the other hand, the influence of the historical context is also important because it allows the change from one sector to another. For example, in the context of agrarian reform an agricultural entrepreneur went into mining and otherwise, during the Fujimori government (1990-2000) a mining entrepreneur moved to agriculture. 
That is, based on government policies, they sought to adapt to where they could be given greater opportunities.

\subsection{Influence of a guild's membership in the construction of representations}

With the passage of time the entrance of the business guild as experience gains more strength to the representations. According to what has been seen, although the family and education affected, over time, relations with other entrepreneurs are becoming effective and become the platform where they interact. This is explained because there is influence towards the political world. This happens because many of its representatives frequent ministries and commissions of Parliament to defend the interests of their sector and propose proposals regarding certain policies.

As they state, in theory, the policies are reflected by the realization of a government plan that the citizens voted. However, in practice many times the public sector is permanently subject to pressures, influences and advice from the private sector. For that the unions go and do their lobbying and depending on their level of influence, with arguments, with closeness, with empathy, they manage to convince in one way or the other.

The negotiation of interests between the political world and the unions is naturalized. The mentality consists of negotiation as something natural between people. That is, we have to agree on our interests and see how far it is possible to get because, in order for the union activity to develop normally, the existence of a democratic regime capable of giving stability to the country is essential.

For that to be possible, a union leader must look for "sweetly forced consensus." This implies not having conflicts of interest, seeking the common good, taking as a guide a standard of values and based on that work. Before, for many businessmen of liberal tendency the competition was for favors of the State, where the value of the companies was in their capacity to influence. Today, guilds are thought to have a more promoter role.

In that sense, an interviewee comments that in order to perform properly one must occupy a hinge perspective. The purpose is not to serve the interests of any individual but to work within a certain scale of principles. This allows objective decisions to be made, emphasizing that the positions taken are not only for the benefit of a sector but also of the country. Thus, everyone claims to be very clear about the functions he performs.

On the other hand, the relationships established between entrepreneurs are usually very pragmatic, based on the resolution of specific issues. In the case of elections, trends are regularly present within the committees. For example, in ADEX and the S.N.I, when you are campaigning to be president you must campaign among the committees to present the ideas. However, there are also disputes between several unions and in some periods "we were entrenched on different fronts."

Referred to the relationship with other social groups, the approach depends on the leadership. This can range from only the defense of interests to the opening of several actors with the purpose of making their bond more known. Both perspectives have an argument to legitimize their position: the most critical part refers to the need to concentrate on their work to truly contribute to the nation. On the other hand, the most active part considers that bridges must be laid so that consensus can be reached.

\subsection{Experiences that led to the incorporation of social responsibility}

First, the experience of incorporating social responsibility programs stems from the need for an optimal business environment. There is a mixture between Christian solidarity and pragmatism of companies so that they can develop within an auspicious environment. While some social responsibility programs are productive oriented, others contribute through advice and the introduction of new technologies.

Finally, a topic that emerged from the conversations was the idea of doing the right thing. This is defined as the possibility that people can fulfill their desires without poverty being an impediment. There is also talk, on the other hand, of the urgency of accompanying the State in decision-making because there are still serious problems and the government needs everyone's help.

We see then that relating through social responsibility is a way of responding to the inequality in the country. This constitutes a way of addressing the problems that we have not yet resolved as a country. 
These actions constitute attempts to contribute to the community, which does not contradict the search for profits.

\section{Conclusions}

We can conclude that, first, experiences arise in the following spaces: families, educational centers, and professional associations. Within these places, the group is cohesive because to the extent that entrepreneurs interact with entrepreneurs, they form a "common spirit" and share certain values. The role played by these spaces serves to integrate into Peruvian society but differentiating itself with the purpose of leading.

On the other hand, social networks are built throughout the early stages of professional training. These are reinforced as each individual adapts them according to the objectives set. The person can thus "take advantage" of the use of these networks in order to improve their contacts both within the business world and in other spheres of social life.

A first point of reference is the family. In the conversations, we have been able to appreciate that there was much influence of the family in the process of formation of the individual, later becoming social capital for the person. On the other hand, these networks are reinforced with the entrance to the school and the study of their university careers and are being reinforced by the place where they work.

The main characteristic of these networks of sociability is the mutual recognition as equal pairs between individuals located in different spheres of power. These can be as much of the business world with the politician as in civil society organizations. One is thus generating, over the years, networks that take advantage of according to their needs. This allows an exchange of information that provides utility to perform a specific action and generate more effective ways of communication to see to what extent my action can generate some result.

These networks of sociability influence the extent to which they constitute points of reference and future actions against a fact. Thus, the person who belongs to an institution can know in advance what could happen if a certain phenomenon occurred. On the other hand, the person can also within their field reaffirm their position and capitalize on it, to generate more favorable conditions for their interests and facilitate the transit from one world to another.

From all things seen, the importance of social networks in the generation of a vision of society is fundamental. This is because it is the frame of reference for people to function socially and reaffirm their position of domination within their own group.

\section{References}

[1] ALCORTA, Ludovico. Concentración y centralización de capital en el Perú. Fundación Friedrich Ebert. Lima. 1987.

[2] ALCORTA, Ludovico. El nuevo capital financiero: grupos financieros y ganancias sistemáticas en el Perú. Fundación Friedrich Ebert. Lima. 1992.

[3] ANAYA, Eduardo. Los grupos de poder económico: un análisis de la oligarquía financiera. Editorial Horizonte. Lima. 1990.

[4] ANDERSON. Benedict. Comunidades imaginadas: reflexiones sobre el origen y difusión del nacionalismo. Fondo Cultura Económica. México D.F. 1993.

[5] BALIBAR, Etienne e Immanuel WALLERSTEIN. Raza, nación y clase. IEPALA. Madrid. 1988.

[6] BALIBAR, Etienne. Nosotros, ¿ciudadanos de Europa?: las fronteras, el Estado y el pueblo. TECNOS. Madrid. 2003.

[7] BOURDIEU, Pierre. Las estrategias de la reproducción social. Siglo XXI. Buenos Aires. 2011.

BURGA, Manuel y Alberto FLORES GALINDO. Apogeo y crisis de la República Aristocrática. Ediciones Rikchay Perú. Lima. 1980. 
[8] CAMPODÓNICO, Humberto y Francisco Durand. Poder empresarial y sociedad civil en Sudamérica. DESCO. Lima. 2018.

[9] CASTILLO, Manuel. La burguesía industrial y el reformismo militar: 1968-1975.

[10] CHATTERJEE, Partha (2002). Comunidades imaginadas: ¿por quién? Historia Caribe. 7 (2). 43 52.

[11] CHATTERJEE, Partha. La nación en tiempo heterogéneo y otros estudios subalternos. Siglo XXI. Buenos Aires. 2008.

[12] COMEX PERÚ. Negocios Internacionales. Año XX. 2010.

[13] COTLER, Julio. Clases, Estado y Nación en el Perú. IEP. Lima. 1978.

[14] COTLER, Julio. Los empresarios y las reformas económicas en el Perú. Documento de trabajo $\mathrm{N}^{\circ}$ 91. IEP. Lima. 1998.

[15] DRINOT, Paulo. La seducción de la clase obrera: trabajadores, raza y la formación del Estado peruano. IEP. 2015.

[16] DURAND. Francisco. Cuando el poder extractivo captura el Estado: lobbies, puerta giratoria y paquetazo ambiental en el Perú. OXFAM. Lima. 2016.

[17] DURAND, Francisco y Fernando Eguren. ¿Liberalismo o mercantilismo? Concentración de la tierra y poder político en el Perú. CEPES. 2018.

[18] ESCALANTE, Fernando. Historia mínima del neoliberalismo. La Siniestra. 2017.

[19] GARCÍA-HUIDOBRO, Rosario. La narrativa como método desencadenante y producción teórica en la investigación cualitativa. EMPIRIA: Revista de Metodología de las Ciencias Sociales. 34. 2016. 1. 155-178.

[20] GESSAGHI, Victoria (2015) Ser sencillo, ser buena persona: clasificaciones morales y procesos de distinción en las experiencias educativas de la "clase alta" argentina. Pro-Posições. 26 (1) 33-50.

[21] GESSAGHI, Victoria. (2011) La experiencia etnográfica y la clase alta: ¿nuevos desafios para la antropología? Boletín de Antropología y Educación. 03 (1) 17-26.

[22] GESSAGHI, Victoria. (2012) El trabajo de formación de la clase alta argentina: un abordaje desde la antropología social. Intersecciones en Antropología. 13 (1). 393-408.

[23] GESSAGHI, Victoria. Educación en la clase alta argentina: entre la herencia y el mérito. Siglo XXI. Buenos Aires. 2016.

[24] GILBERT, Denis. La oligarquía peruana: historia de tres familias. Editorial Horizonte. Lima. 1982.

[25] HOBSBAWN, Eric. Naciones y nacionalismo desde 1780. Crítica. Barcelona. 1997.

[26] JACHOMOWITZ, Luis. Hombres, minas y pozos (1896-1996): un siglo de minería y petróleo en el Perú. SNMPE. 1996.

[27] JANAMPA, Ana Sofía. 2013. "Rubias al pomo: la belleza y el arreglo personal femenino en sectores altos de La Molina". Tesis de Licenciatura: PUCP. 
[28] KOGAN, Luiba. "Relaciones de género en las familias de sectores altos de Lima". Debates en Sociología. 23. 1999. 191.208.

[29] MALPICA, Carlos. Los dueños del Perú. Editorial PEISA. Lima. 1964.

[30] MARSAL. Juan (1978). Nación, nacionalismo y ciencias sociales. REIS. 78 (4) 29-46.

[31] PALTI, Elías. La nación como problema: los historiadores y la cuestión nacional. Fondo Cultura Económica. Buenos Aires. 2003.

[32] PANFICHI, Aldo y Felipe PORTOCARRERO. Mundos interiores: Lima 1850-1950. Fondo Editorial de la Universidad del Pacífico. Lima. 1995.

[33] PEASE, Henry. El ocaso de la oligarquía. El CID editor. Lima. 1979.

[34] PORTOCARRERO, Gonzalo y Milagros SAENZ. La mentalidad de los empresarios peruanos: una aproximación a su estudio. Fondo Editorial de la Universidad del Pacífico. Lima. 2005.

[35] PORTOCARRERO, Gonzalo. Empresarios, sociedad nacional de industrias y proceso político: 1950-1968. PUCP. 1976.

[36] RAMOS, Leónidas. Redes de lobby informal de los gremios empresariales frente a la administración pública del Ministerio de Economía y Finanzas del Perú al momento de debatir la propuesta de la Ley General del Trabajo (2011-2012). Tesis PUCP. 2014.

[37] RENIQUE, José Luis. "Esperanza y fracaso en la historia del Perú", en: PASARA (editor). El Perú en el siglo XXI. PUCP. Lima. 2008)

[38] REYES. Alejandro. Calixto Romero: para quitarse el sombrero. Palmas del Espino S.A. Lima. 2008.

[39] SOCIEDAD NACIONAL DE PESQUERIA. Pesca Responsable: Revista Institucional de la Sociedad Nacional de Pesquería. Año XVII. Edición 91. Agosto 2015.

[40] STRAUSS, Anselm y Juliet CORBIN. Bases de la investigación cualitativa: Técnicas y procedimientos para desarrollar la teoría fundamentada. Editorial de la Universidad de Antioquia. Medellín. 2002.

[41] VALDERRAMA, Mariano y Patricia LUDMANN. La oligarquia terrateniente: ayer y hoy. Fondo Editorial PUCP. Lima. 1979.

[42] VAZQUEZ, Enrique. Estrategias de poder: Grupos económicos en el Perú. Fonde Editorial de la Universidad del Pacífico. Lima. 2004.

[43] VV.AA. Comité textil de la Sociedad Nacional de Industrias: panorama histórico de la actividad textil. Fondo Editorial de la PUCP. Lima. 1995.

[44] VV.AA. Etnografías contemporáneas III: Las narrativas en la investigación antropológica. Fondo Editorial de la Universidad Nacional de Colombia. Bogotá. 2016.

[45] VV.AA. La oligarquía en el Perú: 3 ensayos y una polémica. IEP. Lima. 1969.

[46] WALLERSTEIN, Immanuel. Abrir las ciencias sociales: informe de la comisión Gulbenkian para la reestructuración de las ciencias sociales. Siglo XXI Editores. México DF. 2006. 
